\title{
Medical ethics and Islam: principles and practice
}

\author{
A R Gatrad, A Sheikh
}

\begin{abstract}
A minimum level of cultural awareness is a necessary prerequisite for the delivery of care that is culturally sensitive. In this paper we simplify and highlight certain key teachings in Islamic medical ethics and explore their applications. We hope that the insights gained will aid clinicians to better understand their Muslim patients and deliver care that pays due respect to their beliefs. (Arch Dis Child 2001;84:72-75)
\end{abstract}

Keywords: medical ethics; Islam

Central to discussions concerning ethics, and medical ethics in particular, must lie an appreciation of the beliefs, perspectives, and conceptual frameworks used by our patients (boxes 1 and 2). ${ }^{12}$ This task has been made more complex in recent times following the large scale migration of peoples subscribing to moral and ethical paradigms other than those of JudeoChristianity that have historically shaped British culture. ${ }^{3}$ The National Health Service (NHS), as is the case with the other major British institutions, was originally created to serve a relatively homogeneous population. For many of those who trace their origins from other than a white European lineage it is clear, and distressing at times, that the NHS has found it difficult to adapt to the needs of minority groups. ${ }^{4}$

Box 1: Defining medical ethics ${ }^{2}$

Analytical activity in which concepts, assumptions, beliefs, attitudes, emotions, reasons, and arguments underlining medico-moral decision making are examined critically

Manor Hospital, Walsall NHS Trust, Moat Road, Walsall WS2 2PS, UK A R Gatrad

Department of Primary Care and General Practice, Imperial College School of Medicine, London, UK A Sheikh

Correspondence to: Dr Gatrad drgatrad@hotmail.com

Accepted 23 August 2000
The 1991 Census revealed that almost 6 per cent of the UK population classified themselves as belonging to a minority ethnic group. ${ }^{5}$ With no formal place for transcultural studies in either the undergraduate or postgraduate training of British doctors, it is little wonder that clinicians face problems in tailoring care to the needs of minority ethnic communities. The response from some quarters has been to call for a Universal Ethical Code that embraces and includes the domains of medicine and bioethics. ${ }^{6}$ An alternative approach, and one that we favour, in view of the well described tendency of the dominant cultures to impact on minority perspectives through acculturation, is for ethical pluralism to be allowed to flourish. ${ }^{78}$ In this paper we share our knowledge, gained from readings, attending seminars and conferences, and above all, experiences "from the bedside" of certain principles and practices that may aid clinicians in providing care within an appropriate ethical context for Muslims-Britain and Western Europe's largest religious minority.

\section{Islam and Muslims}

Tracing its origins to the same Semitic soil that bore Judaism and Christianity, Islam continues to deeply influence the beliefs, values, and customs of an estimated one fifth of the human race. Yet, despite this commonality of descent, and the presence of Muslim communities in Britain for well over four centuries, Islam is poorly understood by the host population. ${ }^{9}$ Its most profound tenet is a belief in Monotheism, summarised in the Declaration of Faith: "There is no deity save God, and Muhammad is the Messenger of God". Whispered almost universally by Muslims into the ear of their newborn or a dying loved one, the daily life and body of Muslim communities, including the 1.5-2 million strong British Muslim community, pivot around this very statement. Life's very purpose then is to realise the Divine, a purpose that is achievable only through a conscious commitment to the teachings of Sacred Law. Transmission and instruction in matters of Law was the role par excellence of the Emissaries of God, of whom Muhammad was but the last link in a chain that included such luminaries as Abraham, Moses, and Jesus of Nazareth. Sacred Law for Muslims is an all embracing entity, dealing with all aspects of human existence. ${ }^{10}$

\section{Islamic medical ethics}

THREE SOURCES OF SACRED LAW

The two primary sources of Law are:

- The Qur'an (Koran) - the Holy Text believed by Muslims to be the direct word of God 
- The Sunnah-the example, whether in word or deed, of the Prophet Muhammad incorporated in Islamic scriptures. ${ }^{11}$

The third source is:

- Ijtihad-the law of deductive logic.

Before discussing this third source we need to appreciate the guiding principles and framework of Islamic philosophy which help resolve some moral and ethical dilemmas of today (box 3). Since Islam admits no clergy, the "learned" (Ulema), often scholars from Islamic universities such as Al-Azhar in Cairo, are charged with interpreting and contextualising religious teachings for the wider Muslim community. Recent scientific and technological advances have resulted in a proliferation of a range of complex issues that have produced ethical dilemmas for healthcare professionals, patients, and society at large. Responding to this challenge, many Ulema have concluded that, in situations requiring specialist knowledge (for example, decisions concerning medical practice), the somewhat novel concept of a "consensus edict" is preferable. For rulings pertaining to medicine these consensus groups will typically include a broad and diverse representation of Ulema and specialist clinicians from relevant disciplines, the latter responsible for providing the necessary background information. The decision making process is typically transparent with members of the wider community able to scrutinise the arguments employed and the textual material underpinning these edicts. Counter arguments may be presented, and it is not unusual for two or more seemingly contrasting opinions to coexist. In such cases individuals are, in principle, free to choose whichever judgement they find most agreeable, though in practice many will choose to remain loyal to their particular school of thought.

\section{Box 3: The guiding principles of Islamic Law \\ - Maintenance of life \\ - Protection of an individual's freedom of belief \\ - Maintaining the intellect \\ - Preservation of honour and integrity \\ - Protection of property}

The process of deductive logic described above is known as Ijtihad and this forms the third source of Islamic Law. It is Ijtihad that provides Sacred Law with its dynamism, allowing it to remain relevant when responding to novel challenges and concerns that regularly arise in the Muslim culture which values learning and the scientific process. ${ }^{12}$ One example, and one that is in time likely to bring considerable health benefit to communities worldwide, is the move towards outlawing cigarette smoking on the grounds that its adverse consequences to health are now well established. The more culturally aware of British health authorities have responded by putting the "quit smoking" message within an appropriate religious framework when targeting Muslim communities.
Religious texts commonly used in deliberations on medical ethics

Below are texts that are commonly used in judgements relating to health and healthcare provision, and examples of the ways in which such teachings may be applied.

GENETIC MANIPULATION, ASSISTED CONCEPTION, AND ADOPTION

\section{We (God) created Man in the most perfect form. ${ }^{13}$}

Often used to explain that each human life has its own inherent value and goodness. Humans however also have the capacity for autonomy and self determination and thus have the choice of pursuing a course of action that remains true to their innate pure state or following an immoral path. Whilst genetic research and gene therapy may have positive uses in serving to restore health (and in the process integrity), care must be taken to ensure that other Islamic principles are not violated. An accurate and complete knowledge of one's pedigree is a fundamental human right; only somatic cell lines should therefore be used in transplantation of genetic material since parental integrity is then not compromised and there is no question of hereditary characteristics being influenced.

Know your genealogy and respect your blood ties. $^{14}$

Children have the right to be born through a valid union (marriage) and to know their parentage fully. Artificial insemination and in vitro fertilisation are therefore licit only if sperm from the woman's spouse is used.

Call the adoptive children by the name of their father. ${ }^{1}$

Adoption is generally frowned on in Muslim culture since the process involves the transfer of parental rights to the adoptive parents. Fostering is however positively encouraged since no similar transfer of parentage occurs. In either case, the surname of the real father should be retained.

PRENATAL SCREENING AND TERMINATION OF PREGNANCY

Each of you will have had his created existence brought together in his mother's womb, as a drop (nutfa) for forty days, then a leech like clot (alaqa) for the same period, then a piece of flesh (mughda) for the same period, after which God sends the angel to blow the spirit (ruh) into him. ${ }^{16}$

On the basis of this text many Muslims conclude that foetal ensoulment occurs 120 days post-conception-an important consideration in discussions regarding termination of pregnancy. ${ }^{17}{ }^{18}$ First trimester chorionic villous biopsy (performed before ensoulment) and advances in therapeutic foetal medicine may in 
time lead to a greater willingness to engage in genetic counselling and prenatal screening.

An existing life, with its responsibilities and ties, takes preference over a developing one. If continuation of pregnancy places a mother's life in danger then all Muslim authorities agree that termination of pregnancy is justified. Termination for any other reason is strongly and consistently discouraged, particularly after ensoulment has occurred.

\section{CHILD ABUSE, DISCIPLINING, AND AUTONOMY}

Say: "My Lord, have mercy upon them (my parents), as they cared for me in childhood". ${ }^{19}$

The parent-child relationship is considered the most important of all human relationships, this forming a reference point for all other human encounters. Both children and parents have mutual rights and responsibilities. Love and respect are the guiding principles underpinning this most special of relationships. Any form of sexual, physical, and emotional abuse of children is thus considered abhorrent within Islamic Law. Islamic teachings, however, do recognise that children may at times need to be disciplined, both in their own interests and also in the interests of the wider society, and this may on occasions involve physical punishment. In such instances, jurists have stipulated that the following conditions must be met: parents must never strike the face or head; minimal force should be used, and in particular, no bruising should result; disciplining should not be performed when parents feel they may lose control. ${ }^{20}$

The pen has been lifted from three: the sleeper until he awakens, the (male) child until his first wet dream, and the insane person until he can reason. ${ }^{21}$

The 1989 Children's Act states that age of consent is when a child reaches their sixteenth birthday, or younger, if a doctor deems a child capable of understanding and making decisions. In Islamic law, the age of majority (and hence full autonomy) is dependent on physiological maturation, this being defined for males by the first nocturnal emission and for females by menarche. ${ }^{21}$

\section{END OF LIFE ISSUES AND BRAIN DEATH}

By him in whose hand is my soul, the miscarried foetus draws his mother into paradise by his umbilical cord when she seeks reward for his loss from God. ${ }^{22}$

\section{Every child dies in the true faith. ${ }^{22}$}

Children are born pure according to the teachings of Islam, and those who remain true to their innate nature and abide by the teachings of Sacred Law, are considered whole or healthy. If death is decreed we remind relatives that as children are pure they are assured of bliss in the eternal abode of the hereafter, and furthermore will be their forerunners in Paradise.
Whosoever takes a human life, for other than murder or corruption in the earth, it is as if he has taken the life of all of mankind. ${ }^{23}$

No one is authorised deliberately to end life, whether one's own or that of another human being. Saving life is encouraged, and reducing suffering with analgesia is however acceptable, even if, in the process, death is hastened. This rule is based on the central teaching that "actions are to be judged by their intentions". Withdrawal of food and drink to hasten death is therefore not allowed.

In 1987, Rahman, the US based Muslim philosopher expressed the view that relentless artificial prolongation of life is not in keeping with Islamic ethos unless there is evidence that a reasonable quality of life would result. ${ }^{24}$ The majority of Muslim authorities will consider "brain stem" death acceptable grounds to discontinue life support therapy; three independent physicians, of whom at least one must be a neurologist, should however make the diagnosis. A minority opinion is that the notion of brain stem death is inappropriate, for it is rooted in the Cartesian dualism that characterises biomedicine. It is argued that death criteria which remain true to the essence of the Semitic traditions, namely the point at which the soul departs, be identified and used for end of life decisions.

Withdrawing treatment from any patient, such as a child seriously affected by a hereditary neuromusclar disease, or curtailing treatment in a neonate with severe hypoxic encephalopathy, is never easy. This decision is on occasions, however, somewhat easier for Muslim doctors, such as ourselves, when dealing with Muslim families with whom we share a common heritage and world view. In such circumstances, after making clear that the child's interests are our foremost consideration, it is often possible to make use of Islamic teachings in counselling parents regarding the difficult decisions that lie ahead. We remind parents of God's Omnipotence and the transient nature of our earthly sojourn in contrast to the abiding reality of the hereafter. The exact time of death is a matter of Divine decree over which we as fellow human beings are ultimately bystanders. In these situations we show guarded confidence, yet discuss the real possibility of worse to come, sometimes suddenly and catastrophically. The ensuing "dynamic dialogue" in which we engage is thus rooted in the individual and collective narrative of the family for whom we provide care.

\section{POSTMORTEM EXAMINATIONS AND ORGAN TRANSPLANTATION}

Breaking the bone of the dead is akin to breaking the bone of the living. ${ }^{25}$

On the basis of this Qur'anic text some scholars have deduced that it may be possible for the deceased to feel pain-one of the reasons for the general reluctance of Muslims to allow postmortem examinations. Others, however, opine that the text obliges the Muslim commu- 
nity to deal humanely with fellow human beings whether in life or in death. In future magnetic resonance necropsy may offer an alternative to formal open whole body postmortem examination. ${ }^{26}$ This innovation is becoming increasingly widespread in many pathology departments in the UK. ${ }^{27}$

Organ transplantation is now encouraged in many Arab Muslim countries, and considered by some as a "perpetual" charitable act. This issue has not been as well debated among the South Asian Muslim community, at least in part because until very recently the subject was only one of academic interest in these countries. $^{28}{ }^{29}$ Sale of bodily organs is categorically prohibited. Xenotransplantation options are likely to increase in the foreseeable future and Muslim opinion about the acceptability and, if so, the prerequisite conditions (is transplant of organs from pigs acceptable when consumption of pork is forbidden?), remains divided.

\section{NECESSITY ALLOWS THE PROHIBITED}

But if one is compelled by necessity, neither craving nor transgressing - there is on him no sin, for indeed God is Clement, Merciful. ${ }^{30}$

In the case of absolute necessity, where religiously lawful alternatives do not exist, Islamic teaching allows for Sacred Law to be suspended, temporarily if possible. The use of pork insulin and heart valves from pigs has been ruled acceptable by many Ulema on the basis of this principle.

\section{Conclusions}

A minimum level of cultural awareness is a necessary prerequisite for the delivery of care that is culturally sensitive. ${ }^{31-33}$ Once equipped with such understanding it is possible to move beyond the "recipe book" approach to dealing with minority traditions, offering the opportunity for experiential learning. In this paper we have simplified and highlighted certain key teachings in Islamic medical ethics and explored their applications. Though introductory, we hope that the insights gained will aid clinicians to better understand their Muslim patients and deliver care that pays due respect to their beliefs.

1 Department of Health. The patient's charter. London: DoH, 1999:4.

2 Macnair T. Medical ethics. BMf Classified 1999:2-3.

3 Henley A, Schott J. Culture, religion and patient care in a multi-ethnic society. London: Age Concern England, 1999: $1-30$.

4 Mackintosh J, Bhopal R, Unwin N, Ahmad N. Step by step guide to epidemiological health needs assessment for minority ethnic groups. Newcastle: University of Newcastle, 1998: $1-22$.

5 Anwar M. Muslims in Britain: demographic and socioeconomic position. In: Sheikh A, Gatrad AR, eds. Caring for Muslim patients. Oxford: Radcliffe, 2000:3-16.

6 Singer P. How are we to live? Oxford: Oxford University Press, 1997.

7 Helman CG. Culture, health and illness. Oxford: ButterworthHeinemann, 1994:2-5.

8 Kai J, ed. Valuing diversity. London: RCGP, 1999:1-1.4.

9 Matter N. Islam in Britain 1558-1685. Cambridge: Cambridge University Press, 1998:1-20.

10 Ahmed AS. Living Islam. London: BBC Books, 1993:2156.

11 Doi AR. Shar'iah: The Islamic Law. London: Ta Ha, 1984: 2-84.

12 Butt N. Science and Muslim societies. London: Grey Seal, 1991:37-88.

13 Ali YA. The meaning of the Glorious Quran 95:4. Cairo: Dar al-Kitab, 1938. (Translation modified).

14 Ben Hamida F. Islam and bioethics. In: European Network of Scientific Co-operation on Medicine and Human Rights. The human rights, ethical and moral dimensions of health care. Strasbourg: Council of Europe Publishing, 1998:84.

15 Ali YA. The meaning of the Glorious Quran 33:5. Cairo: Dar al-Kitab, 1938. (Translation modified).

16 Al-Haddad A. The lives of man. London: Quilliam, 1991:16.

17 El-Hashemite N. The Islamic view in genetic preventive procedures. Lancet 1997;350:223.

18 Salihu HM. Genetic counselling among Muslims: questions remain unanswered. Lancet 1997;350:1035.

19 Ali YA. The meaning of the Glorious Quran 17:24. Cairo: Dar al-Kitab, 1938. (Translation modified)

al-Kitab, 1938. (Translation modified).

21 Kelle NHM. Reliance of the traveller. Maryland: Amana,

1994:42-6.
22 Tarazi N. The child in Islam. Indiana: ATP, 1995:84-7.

22 Tarazi N. The child in Islam. Indiana: ATP, 1995:84-7. al-Kitab, 1938. (Translation modified).

24 Rahman F. Health and medicine in the Islamic tradition. Chicago: ABC, 1998:108-9.

25 al-Asqalani AIH. Bulugh al-Maram. Riyadh: Dar-us-Salam Publications, 1996:199-200.

26 Bisset R. Magnetic resonance imaging may be an alternative to necropsy. $B M \mathcal{F} 1998 ; 317: 145$.

27 National CEPOD Report. Extremes of age. CEPOD, 1999:54.

28 Sheikh A. Death and dying-a Muslim perspective. $\mathcal{F} R$ Soc Med 1998;91:138-40.

29 Gatrad AR. Muslim customs surrounding death, bereavement, post-mortem examinations, and organ transplants. BMF 1994;309:521-3.

30 Ali YA. The meaning of the Glorious Quran 16:117. Cairo: Dar al-Kitab, 1938. (Translation modified).

31 Sheikh A, Gatrad AR, Dhami S. Culturally sensitive care for the dying is a basic human right. BMF 1999;319:1073.

32 Qureshi B. Transcultural medicine. London: Kluwer, 1994:ix.

33 Yee L. Breaking barriers: towards culturally competent general practice. London: RCGP, 1997:28-33. 